\title{
Comparison of three PCR techniques for detecting cytomegalovirus (CMV) DNA in serum, detection of early antigen fluorescent foci and culture for the diagnosis of CMV infection
}

\author{
P. C. EVANS, J. J. GRAY*, T. G. WREGHITT*, R. E. MARCUS $\dagger$ and G. J. M. ALEXANDER \\ University of Cambridge School of Clinical Medicine, *Clinical Microbiology and Public Health Laboratory and \\ †Department of Haematology, Addenbrooke's NHS Trust, Hills Road, Cambridge CB2 $20 Q$
}

\begin{abstract}
Three PCR assays were developed for detection of cytomegalovirus (CMV) DNA in serum and were evaluated with samples from organ transplant recipients. The Qiamp Blood Kit was efficient for extraction of DNA from sera. Single-round PCR of a 293-bp region of CMV DNA was sensitive and highly specific for CMV targets and was more sensitive than detection of early antigen fluorescent foci (DEAFF) testing or isolation of CMV from buffy coat by cell culture. The results of a significant proportion of buffy coat samples were not interpretable because of toxicity in conventional culture or DEAFF tests. A non-competitve quantitative PCR test and semi-quantitative PCR test for the detection of CMV DNA in serum yielded comparable results for samples taken serially from three bone marrow transplant recipients. Single-round PCR was superior to conventional techniques for the diagnosis of CMV infection, was simple to perform and was completed rapidly. The semi-quantitative technique has added advantages where quantification is important.
\end{abstract}

\begin{abstract}
Introduction
Cytomegalovirus (CMV) is a major cause of mortality and morbidity in organ and bone marrrow transplant recipients [1-4]. Early, pre-emptive treatment of patients with active CMV infection with ganciclovir (before the development of clinical symptoms) has been shown to improve patient survival and reduce CMV disease $[5,6]$. However, a reliable, specific, sensitive and rapid method for the diagnosis of active CMV infection is essential for early, targetted ganciclovir treatment and to avoid unnecessary therapy with the risk of myelotoxicity.
\end{abstract}

Single-round, quantitative and semi-quantitative PCR assays for the detection of CMV DNA in serum were developed and compared with the detection of CMV early antigen fluorescent foci (DEAFF) and cell culture for the diagnosis of $\mathrm{CMV}$ infections in transplant recipients.

Received 5 March 1998; revised version received 22 March 1999; accepted 27 March 1999.

Corresponding author: Dr G. J. M. Alexander (e-mail: gja1000@cam.ac.uk).

\section{Material and methods}

Patients and testing of clinical samples

Clotted and heparinised blood samples were collected between Jan. 1993 and Jan. 1995 from 32 liver transplant and 17 non-autologous bone marrow transplant recipients. These were collected twice weekly during hospitalisation, then at each visit to the out-patient clinic, until 6 months after transplant. Samples for establishing PCR assays were then selected from this pool according to assay requirements. Heparinised blood samples taken at the same time as clotted blood for PCR were always tested in parallel by DEAFF and cell culture. A total of 89 serum and buffy coat samples was tested in parallel by PCR and DEAFF; 76 buffy coat samples were also tested by culture.

Samples were chosen from three bone marrow transplant patients who developed active CMV infection to compare quantitative and semi-quantitative PCR tests. A diagnosis of active CMV infection in bone marrow transplant recipients was made in patients who had pyrexia, pneumonia, retinitis, leukopenia or thrombocytopenia in conjunction with positive DEAFF or CMV culture. 
Patient 1 was a 34-year-old man who underwent allogeneic bone marrow transplantation for multiple myeloma. CMV serology was donor negative/recipient positive. Despite ganciclovir prophylaxis, active CMV infection was manifest on day 67 and, therefore, occurred concomitantly with the onset of symptoms (pyrexia), but 25 days before the diagnosis of CMV pneumonitis. Ganciclovir therapy was initiated on day 67 , but this patient did not respond initially and died at 126 days. Patient 2 was a 34-year-old man who underwent unrelated bone marrow transplantation for multiple myeloma. CMV serology was donor negative/recipient positive. Serum PCR for CMV was initially positive on day 45 , which was 85 days before symptoms (day 130, CMV retinitis). This patient appeared to clear CMV, but urine was positive by PCR and DEAFF test on day 100 until day 118 and CMV retinitis was diagnosed on day 130; CMV infection was subclinical until the diagnosis of CMV retinitis. This patient responded clinically to ganciclovir treatment (initiated on day 130), but died on day 309 from progressive multifocal leuco-encephalopathy. $\mathrm{Pa}-$ tient 3 was a 44-year-old man who underwent allogeneic bone marrow transplantation for multiple myeloma. CMV serology was donor negative/recipient positive; serum was initially positive on day 65 , which was 6 days after the onset of symptoms (pyrexia). This patient cleared CMV after ganciclovir treatment from day 59 to day 66 . Urine was not positive by PCR. This patient made a full recovery, but died 10 months after transplantation from recurrent primary disease.

\section{Processing of clinical samples}

Whole blood was allowed to clot overnight at $4{ }^{\circ} \mathrm{C}$; serum was collected after centrifugation at $2500 \mathrm{~g}$ for $10 \mathrm{~min}$ and stored at $-20^{\circ} \mathrm{C}$ before DNA extraction and PCR. Whole blood $(10 \mathrm{ml})$ was added to preservativefree heparin (250 units) and stored at $4^{\circ} \mathrm{C}$ overnight. Buffy coat samples (collected from the interface between red blood cells and plasma) were then removed with a pasteur pipette and tested immediately by DEAFF or cell culture, or both.

\section{Serum sample preparation}

Proteinase $K$ method. DNA was extracted from serum according to the method of Wolf and Spector [7]; $50 \mu 1$ of serum were mixed with $50 \mu \mathrm{l}$ of double strength Amplitaq buffer $(10 \times$ stock; Perkin Elmer-Cetus $)$ before three freeze-thaw cycles and incubation $\left(60^{\circ} \mathrm{C}\right.$ for $1 \mathrm{~h}$ ) with proteinase $\mathrm{K}$ (Boehringer-Mannheim) $120 \mu \mathrm{g} / \mathrm{ml}$. This was followed by heating at $95^{\circ} \mathrm{C}$ for $10 \mathrm{~min}$ and centrifugation ( $12000 \mathrm{~g}$ for $5 \mathrm{~min}$ ) to remove debris. The supernate was used for PCR amplification.

Qiagen method. DNA was extracted from $200 \mu 1$ of serum with the Qiamp Blood Kit (Qiagen): $25 \mu \mathrm{l}$ of Qiagen protease $(19.23 \mathrm{mg} / \mathrm{ml})$ and $200 \mu \mathrm{l}$ of buffer
AL (Qiagen) were mixed with $200 \mu \mathrm{l}$ of serum. After incubation at $70^{\circ} \mathrm{C}$ for $10 \mathrm{~min}, 210 \mu \mathrm{l}$ of isopropanol were added and the mixture was applied to a silicon resin (Qiamp spin column, Qiagen) by centrifugation and washed three times with $500 \mu 1$ of buffer AW (Qiagen). DNA was eluted into $200 \mu \mathrm{l}$ of pre-heated $\left(70^{\circ} \mathrm{C}\right)$ water after incubation at $70^{\circ} \mathrm{C}$ for $10 \mathrm{~min}$. This eluate was used for PCR amplification.

\section{PCR of a 293-bp region of the immediate early gene of $C M V$}

Primer sequences for amplification of a 293-bp region of CMV major immediate early gene 1 , exon 4 were described by Taylor-Wiedeman et al. [8]. Prepared sample $(50 \mu \mathrm{l})$ was amplified with reaction buffer (Perkin Elmer-Cetus), $2 \mathrm{mM} \mathrm{MgCl}_{2}$ (Perkin ElmerCetus), $200 \mu \mathrm{M}$ each dNTP (Pharmacia), $1 \mu \mathrm{M}$ sense primer (5'-AAGTGAGTTCTGTCGGGTGCT-3'; Pharmacia) and $1 \mu \mathrm{M}$ antisense primer (5'-TCCTCTGATTCTCTGGTGTCAC-3'; Pharmacia). A thermal cycler (Omnigene, Hybaid) was used to incubate this mixture at $94^{\circ} \mathrm{C}$ for $5 \mathrm{~min}$ and then at $55^{\circ} \mathrm{C}$ for $5 \mathrm{~min}$. Tubes were then centrifuged briefly before addition of $2.5 \mathrm{U}$ of Amplitaq (Perkin Elmer-Cetus) and $1 \mu 1$ of Perfect Match Enhancer (Stratagene) and overlaid with one drop of mineral oil (Sigma). Reaction mixtures were subjected to 30 thermal cycles $\left(94^{\circ} \mathrm{C}\right.$ for $30 \mathrm{~s}, 55^{\circ} \mathrm{C}$ for $30 \mathrm{~s}, 72^{\circ} \mathrm{C}$ for $90 \mathrm{~s}$ ) and finally $72^{\circ} \mathrm{C}$ for $10 \mathrm{~min}$. After amplification, $30 \mu \mathrm{l}$ of each amplified product were electrophoresed $(60 \mathrm{~V} / \mathrm{cm})$ in an agarose (Sigma) $2 \%$ gel with TAE buffer. Gels were photographed over UV light after staining with ethidium bromide $10 \mu \mathrm{g} / \mathrm{ml}$. Amplification of doubling dilutions of target plasmid DNA followed by agarose gel electrophoresis and ethidium bromide staining, i.e., qualitative PCR, gave a sensitivity of $0.078 \mathrm{fg}$ which is equivalent to 561 template copies [9]. Amplification of a 293-bp fragment was specific for CMV DNA; no amplification of herpes simplex virus (HSV) I and II, Epstein-Barr virus, HHV6, human or Escherichia coli chromosomal DNA was seen. CMV specificity was confirmed by Southern blotting and hybridisation with an oligonucleotide probe (5'-GCCGCATTGAGGAGATCTGCATGAAGGTCT-3').

These PCR test protocols were derived from experiments to optimise assay parameters. Measures were taken to prevent contamination. DNA extraction, reaction mix preparation (in a positive pressure laminar flow hood) and product electrophoresis were conducted in separate rooms with separate pipettes, aerosolresistant tips and reagents. Negative (water) and positive (plasmid) controls were included in each experiment.

\section{Quantitative and semi-quantitative $P C R$}

Construction of plasmids p.IE.PCR and p.IE.PCR.Del. Plasmids designated p.IE.PCR and p.IE.PCR.Del were 
constructed from PCR products. Plasmid p.IE.PCR contained a 293-bp fragment of immediate early (IE) gene DNA (AD 169 strain). The insert sequence was amplified from IE1 gene by PCR with $1 \mathrm{pg}$ of pGEM IEl as target DNA which comprised the $1.8-\mathrm{kb}$ HindIII-EcoR 1 restriction fragment, encoding immediate early genes 1 and 2, cloned into plasmid pGEM (Promega) and was generously supplied by Professor J. G. P. Sissons [7, 8]. Plasmid p.IE.PCR.Del was used to perform quantitative PCR and was identical to the former except for a 50-bp deletion within the IE gene fragment. Recombinant PCR techniques [10] were used to create the 50 -bp deleted insert; primer sequences remained intact. Both inserts were cloned into plasmid pT7/T3 alpha-18 (Life Technologies).

Accurate non-competitive quantification. For each sample, $1 \mathrm{pg}$ of p.IE.PCR.Del (deleted target DNA) was added to $50 \mu 1$ of sample DNA preparation before this mixture was diluted in five doubling dilutions. For each sample, six wild-type-deleted mixture dilutions were amplified. After amplification, the quantity of wild-type and deleted product in each tube was measured and was plotted after regression analysis.

Detection of wild-type and deleted targets. Deleted and wild-type products were distinguished by differential mobility in gel electrophoresis. An automated fluorescence detection technique was adapted from a recent report [11]. PCR was conducted as described above with a fluorescein-labelled sense primer. Subsequently, $30 \mu \mathrm{l}$ of each product was loaded on to a nondenaturing polyacrylamide $6 \%$ gel and electrophoresed in an ABI 373A automatic DNA sequencer (Genescan 1.1 software). The gel was scanned with a $40 \mathrm{~mW}$ argon ion laser at a fixed distance from the wells and fluorescence was detected by a photomultiplier tube. These data were integrated and the fluorescence intensity was presented graphically for each lane loaded. The amount of product (wild-type or deleted) was proportional to the area under the corresponding fluorescence intensity peak.

Semi-quantitative PCR. Semi-quantitative PCR of a single sample was performed in a single tube (without the addition of deleted target molecules); wild-type product was measured as described above. Exogenous controls, comprising doubling dilutions of wild-type target DNA from $5 \mathrm{pg}$ to $0.15 \mathrm{pg}$, were run alongside sample tubes and were used to generate a standard curve from which the initial quantities of wild-type DNA could be calculated.

Comparison of accurate quantitative PCR with semiquantitative $P C R$. Sixteen serum samples from three bone marrow transplant patients, previously shown to be PCR positive, were tested by quantitative and semiquantitative PCR.
Detection of early antigen fluorescent foci (DEAFF)

MRC 5 human embryonic lung fibroblasts were grown to confluence in shell vials with $500 \mu \mathrm{l}$ of Minimal Essential Medium (MEM; Gibco). For inoculation, the medium was replaced with $500 \mu \mathrm{l}$ of specimen and centrifuged $(2500 \mathrm{~g}$ for $30 \mathrm{~min})$. The specimen was then replaced with $500 \mu \mathrm{l}$ of MEM and incubated in an atmosphere of air with $\mathrm{CO}_{2} 5 \%$ at $37^{\circ} \mathrm{C}$ for $24 \mathrm{~h}$. The monolayer was then washed twice in phosphatebuffered saline (PBS), pH 7.2, before fixation in methanol. Mouse monoclonal antibody (MAb) to immediate early antigen (Dako) was diluted 1 in 5 with PBS and $50 \mu \mathrm{l}$ were applied to the monolayer before incubation at $37^{\circ} \mathrm{C}$ for $30 \mathrm{~min}$. The monolayer was washed three times in PBS and $50 \mu \mathrm{l}$ of fluorescein isothiocyanate-conjugated goat anti-mouse antibody (Dako) ( 1 in 500 in PBS) were added. After incubation at $37^{\circ} \mathrm{C}$ for $30 \mathrm{~min}$ the coverslips were washed three times in PBS, once in distilled water and dried in air before examination by epifluorescence microscopy for characteristic fluorescent foci.

\section{Isolation of $C M V$ by cell culture}

MRC 5 fibroblasts were culture in MEM containing fetal calf serum (FCS; Gibco BRL) $2 \%$ in tubes. For $\mathrm{CMV}$ culture, $100 \mu \mathrm{l}$ of specimen were added to confluent fibroblasts in $1 \mathrm{ml}$ of MEM. Tubes were incubated at $37^{\circ} \mathrm{C}$ for up to 3 weeks; MEM was replaced every 7 days. Fibroblasts were inspected daily for evidence of CMV-mediated cytopathic effect; this was observed as focal formation of rounded giant cells.

\section{Results}

\section{Optimisation of serum sample preparation}

Serum samples were collected from three liver transplant recipients with active CMV infection and from healthy CMV antibody-positive and -negative individuals to optimise sample preparation. Samples were subjected to a proteinase K-based extraction technique and a silicon capture-based kit (Qiamp kit), before PCR. CMV DNA was not amplified from serum samples obtained from healthy individuals (CMV antibody-negative or -positive), but was amplified from those experiencing acute $\mathrm{CMV}$ infection. Amplifiable DNA was extracted from blood and serum (Fig. 1) with the Qiamp kit, whereas the proteinase K-based technique was successful only with whole blood.

\section{Comparison of PCR of CMV DNA from serum with culture and DEAFF testing of buffy coat}

PCR amplification of a 293-bp fragment of IE1 gene, exon 4 was specific and sensitive; amplification did not occur with E. coli, human or other herpesvirus DNA 


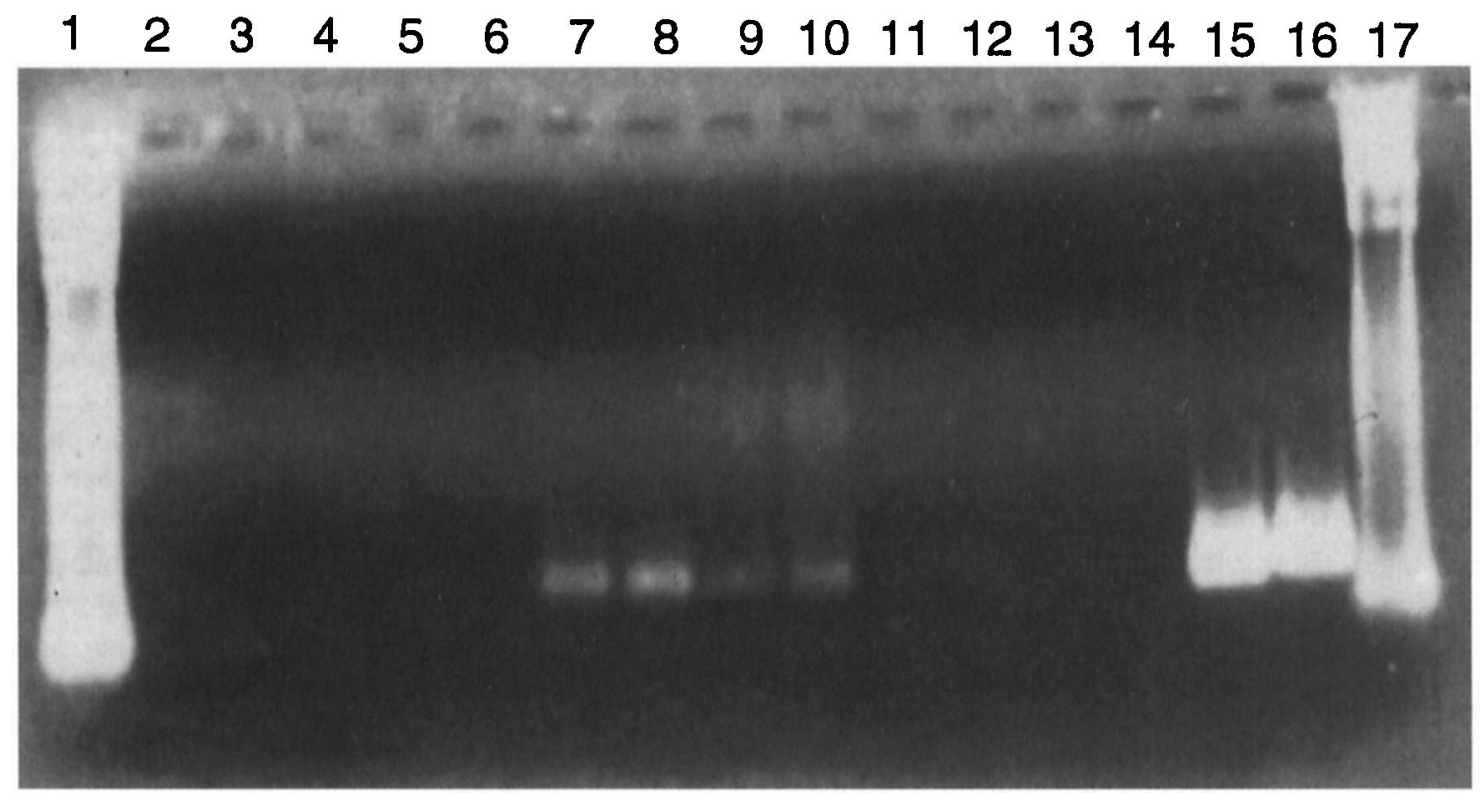

Fig. 1. Qiamp blood kit extraction of amplifiable DNA from serum. DNA was extracted from serum of three patients with active CMV infection by a proteinase K-based technique (lanes 2-6) or the Qiamp blood kit (7-12): $50 \mu 1(\mathbf{3}, \mathbf{5}$, $6,8,10,12)$ or $25 \mu \mathrm{l}(2,4,7,9,11)$ of each preparation underwent PCR and products were electrophoresed on an agarose $2 \%$ gel alongside a $\lambda$ DNA ladder $123 \mathrm{bp}$; Gibco). Negative (water; 13, 14) and positive (100 pg, $50 \mathrm{pg}$ pT7/T3-IE-PCR; 15, 16) controls were included and were PCR negative and positive, respectively. Qiamp extraction (lanes 7-12) was more efficient than a proteinase K-based method and enabled amplification of CMV DNA from all these patients.

and $0.078 \mathrm{fg}$ (561 genomes) of the target DNA could be detected after PCR and agarose gel electrophoresis.

A total of 89 serum and buffy coat samples collected from liver or bone marrow transplant recipients was tested for CMV by PCR and DEAFF; 76 of these were also tested by cell culture (Table 1). Compared to DEAFF and cell culture, serum PCR had a sensitivity of $100 \%$ and $100 \%$, and a specificity of $88 \%$ and $84 \%$, respectively; $17 \%$ and $51 \%$ of buffy coat samples were toxic in the DEAFF test and culture, respectively.

\section{Accurate non-competitive quantification}

An example of quantitative PCR determination of CMV genome copy numbers for a single serum sample is shown in Figs. 2 and 3. Deleted control DNA was added to wild-type DNA before serial dilution, PCR amplification and determination of wild-type and deleted product yield. For each reaction tube, $\log _{10}$ of the initial amount of deleted template was plotted against $\log _{10}$ amount of wild-type and deleted product

Table 1. Comparison of buffy coat testing for CMV by DEAFF or culture with PCR on serum

\begin{tabular}{|c|c|c|c|c|c|c|}
\hline \multirow{2}{*}{$\begin{array}{l}\text { PCR } \\
\text { result }\end{array}$} & \multicolumn{3}{|c|}{$\begin{array}{l}\text { DEAFF result } \\
\quad(\mathrm{n}=89)\end{array}$} & \multicolumn{3}{|c|}{$\begin{array}{l}\text { Culture result } \\
\quad(n=76)\end{array}$} \\
\hline & + & - & toxic & + & - & toxic \\
\hline+ & 0 & 9 & 3 & 0 & 6 & 2 \\
\hline- & 0 & 65 & 12 & 0 & 31 & 37 \\
\hline
\end{tabular}

(Fig. 2). Regression analysis was then performed (Fig. 3). Parallel curves indicated that amplification of deleted and wild-type products had occurred with equal efficiency and a gradient above zero indicated that the reaction was at the exponential phase at the completion of cycling. The amount of initial wild-type DNA was calculated from the ratio wild-type DNA: deleted target DNA, which was derived from the curve.

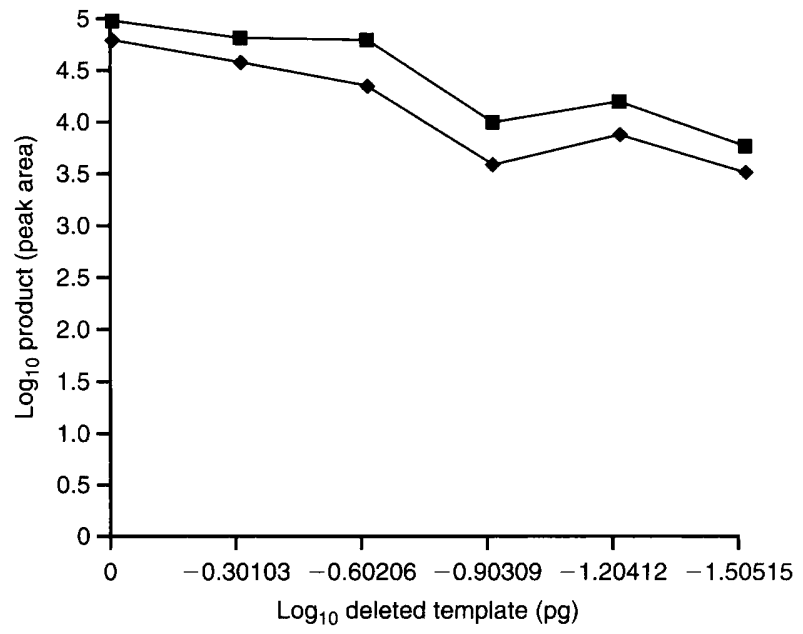

Fig. 2. Quantitative PCR showing $\log _{10}$ deleted template versus $\log _{10}$ product (peak area) for a serum sample from a bone marrow transplant patient (no.1) at 98 days posttransplant subjected to quantitative PCR; ( $\square$ ), full-length product; $(\diamond)$, deleted products. $\log _{10}$ of the area under each corresponding peak observed after Genescan software analysis are shown plotted against the $\log _{10}$ of the amount of deleted template present in the six reactions. 


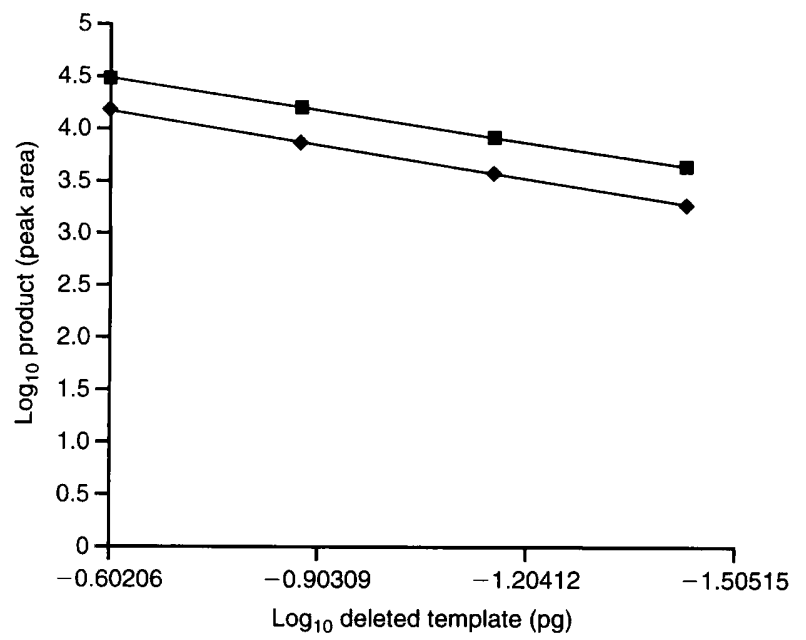

Fig. 3. Regression plot of $\log _{10}$ product (peak area) against $\log _{10}$ deleted template for a serum sample from a bone marrow transplant patient (no.1) at 98 days posttransplant subject to quantitative PCR; $(\boldsymbol{\square})$, full-length product; $(\bullet)$, deleted product. Regression plot of the $\log _{10}$ product (peak area) against $\log _{10}$ deleted template is shown for both deleted and full-length product for four $\mathrm{PCR}$ reactions.

\section{Comparison of quantitative and semi-quantitative PCR}

Non-competitive quantitative PCR and semi-quantitative PCR were compared in tests on sequential serum samples from three bone marrow transplant recipients who developed CMV disease. The samples tested had been shown previously to be positive by qualitative PCR; the results are shown in Figs. 4 and 5.

Accurate quantification allowed discrimination over $3.5 \log _{10}$ whereas semi-quantitation discriminated over $2 \log _{10}$; the latter test may have underestimated the quantity of CMV present after becoming saturated. In contrast, non-competitive quantitative PCR is not prone to such error because each sample is diluted several times. However, the patterns generated by these two tests were essentially similar. For both tests, the maximum viral load was highest in case 1 (CMV pneumonitis), followed by case 2 (CMV retinitis) and lowest in case 3 (pyrexia).

\section{Discussion}

Serum samples were processed efficiently with the Qiamp Blood Kit, which performed better than a proteinase $\mathrm{K}$-based technique. It is possible that serum components acted as non-specific, non-enzymic PCR inhibitors which were not eliminated by the proteinase K-based DNA extraction technique, but were eliminated after Qiamp extraction. Amplification was obtained only from serum samples collected from individuals experiencing episodes of active $\mathrm{CMV}$

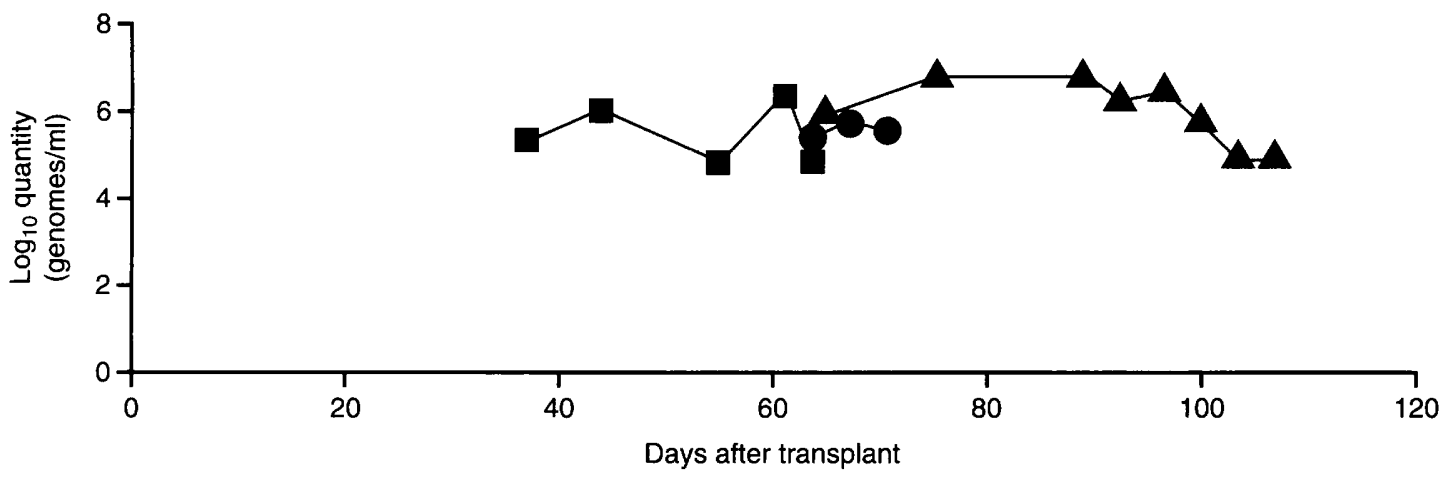

Fig. 4. Semi-quantitative PCR for CMV performed on serum from three bone marrrow transplant recipients with CMV disease. The quantity of CMV genomes in serum for patients $1(\mathbf{\Delta}), 2(\boldsymbol{\bullet})$ and $3(\bullet)$ is shown.

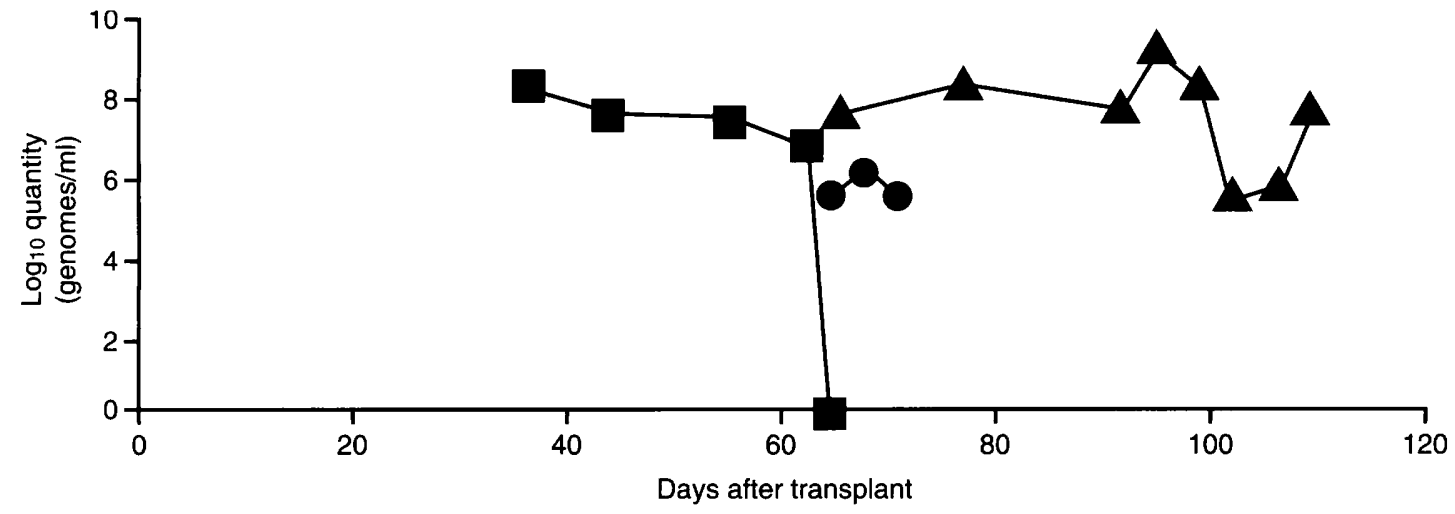

Fig. 5. Quantitative PCR for CMV in three bone marrow transplant recipients. The quantity of CMV genomes in serum for patients $1(\Delta), 2(\bullet)$ and $3(\bullet)$ is shown. 
infection and this specificity was further substantiated by testing clinical samples. Other reports have also demonstrated the inability of single-round PCR to detect CMV in healthy carriers $[12,13]$.

When serum and buffy coat samples from transplant recipients were tested in parallel by PCR and culture of DEAFF, or both, PCR of serum was more sensitive than DEAFF or culture. In fact, none of the serum samples that were positive by PCR was also positive by DEAFF or culture. Nevertheless, the PCR test was shown to be specific by probing with a CMV-specific oligonucleotide probe and all samples that were PCR positive were taken from patients who were experiencing CMV disease (confirmed by urine DEAFF and culture).

Previous reports have shown that PCR testing of whole blood is more sensitive than conventional cell culture $[12,14-18]$ and DEAFF $[12,14,15,18-21]$. Zipeto et al. [12] found that one-third of 293 blood samples taken from a mixed population of transplant recipients, patients with AIDS and neonates gave positive results in PCR tests, but negative results by DEAFF and culture.

Most (13 of 15) of the PCR-positive serum samples were from two bone marrow transplant recipients with severe CMV disease and it is surprising that these samples remained DEAFF- and culture-negative. It is possible that a reduction in the number of lymphocytes tropic for CMV in buffy coat samples in these patients resulted in failure of detection. Furthermore, a high proportion of samples was toxic to the fibroblasts used in the DEAFF test (17\% toxic) and culture (51\% toxic). Some of these 'toxic samples' were taken from patients who were receiving prophylactic ganciclovir treatment (33\% and $31 \%$, respectively). Residual ganciclovir may have been responsible, in part, for the toxicity observed and the inability to culture virus.

For accurate quantitative PCR, a control (flanked with identical primer binding sequences) must be included to compensate for variations in PCR efficiency between samples. To differentiate between sample and control targets, previous workers have created restriction sites by in-vitro mutagenesis [22], introduced single-based permutations and separated products by temperature gradient gel electrophoresis [23], introduced heterologous DNA and differentiated between products by hybridisation $[24,25]$ or generated products of different sizes, easily separated by gel electrophoresis $[11,25$, 26].

In this study, a 50-bp deletion of the wild-type sequence was made by a recombinant PCR technique [10] that allows recombination irrespective of restriction site position. Detection and interpretation of results was easy and did not need radioactive isotopes; fluorescein-labelled PCR products were separated with an ABI automated DNA sequencer.
It is important to amplify a dilution series of each spiked sample; single-point analysis is inaccurate because amplification efficiencies may vary from tube to tube. A dilution series also enables a plateauing or competition between target DNAs to be identified and taken into account. Amplification profiles of wild-type (pT7/T3-IE) and recombinant (pT7/T3-IE.Del) targets mirrored each other. Amplification was exponential after 30 cycles and occurred with equal efficiency; these are important prerequisites for accurate quantification.

Accurate quantification was compared with semiquantification for serum samples taken from three bone marrow transplant recipients. A number of discrepancies arose because 'saturation' and variations in efficiency between tubes cannot be monitored when performing semi-quantitative PCR. However, both tests generated similar results and ranked these three patients identically (based upon maximum viral load). Furthermore, the semi-quantitative PCR test was easier to perform than non-competitive quantitative PCR and has been adopted for future study of liver and bone marrow transplant recipients at Addenbrooke's NHS Trust.

We gratefully acknowledge provision of reagents by Professor J.G.P. Sissons. P.E. was supported by Addenbrooke's Charities.

\section{References}

1. Glenn J. Cytomegalovirus infections following renal transplantation. Rev Infect Dis 1981; 3: 1151-1178.

2. Singh N, Dummer JS, Kusne $\mathrm{S}$ et al. Infections with cytomegalovirus and other herpesviruses in 121 liver transplant recipients: transmission by donated organ and effect of OKT3 antibodies. J Infect Dis 1998; 158: 124-131.

3. Sutherland S, Bracken P, Wreghitt TG, O'Grady J, Calne RY, Williams R. Donated organ as a source of cytomegalovirus in orthotopic liver transplantation. J Med Virol 1992; 37: 170-173.

4. Wingard JR. Viral infections in leukemia and bone marrow transplant patients. Leuk Lymphoma 1993; 11: 115-125.

5. Singh N, Yu VL, Mieles L, Wagener MM, Miner RC, Gayowski T. High-dose acyclovir compared with short-course preemptive ganciclovir therapy to prevent cytomegalovirus in liver transplant recipients: a randomized trial. Ann Intern Med 1994; 120: 375-381.

6. Goodrich JM, Mori M, Gleaves CA et al. Early treatment with ganciclovir to prevent cytomegalovirus disease after allogeneic bone marrow transplantation. $N$ Engl $J$ Med 1991; 325: $1601-1607$.

7. Wolf DG, Spector SA. Early diagnosis of human cytomegalovirus disease in transplant recipients by DNA amplification in plasma. Transplantation 1993; 56: 330-334.

8. Taylor-Wiedeman J, Sissons JGP, Borysiewicz LK, Sinclair JH. Monocytes are a major site of persistence of human cytomegalovirus in peripheral blood mononuclear cells. $J$ Gen Virol 1991; 72: 2059-2064.

9. Evans PC, Gray J, Wreghitt TG, Alexander GJM. Optimisation of the polymerase chain reaction and dot-blot hybridisation for detecting cytomegalovirus DNA in urine: comparison with detection of early antigen fluorescent foci and culture. $J$ Virol Methods 1998; 73: 41-52.

10. Rashtichian A. Novel methods for cloning and engineering genes using the polymerase chain reaction. Curr Opin Biotechnol 1995; 6: 30-36.

11. Karet FE, Charnock-Jones S, Harrison-Woolrych ML et al. Quantification of mRNA in human tissue using fluorescent nested reverse-transcriptase polymerase chain reaction. Anal 
Biochem 1994; 220: 384-390.

12. Zipeto D, Revello MG, Silini E et al. Development and clinical significance of a diagnostic assay based on the polymerase chain reaction for detection of human cytomegalovirus DNA in blood samples from immunocompromised patients. $J$ Clin Microbiol 1992; 30:527-530.

13. Rawal BK, Booth JC, Fernando S, Butcher PD, Powles RL. Quantification of cytomegalovirus DNA in blood specimens from bone marrow transplant recipients by the polymerase chain reaction. J Virol Methods 1994; 47: 189-202.

14. Gerna G, Zipeto D, Parea $M$ et al. Monitoring of human cytomegalovirus infections and ganciclovir treatment in heart transplant recipients by determination of viremia, antigenemia and DNAemia. J Infect Dis 1991; 164: 488-498.

15. Kidd IM, Fox JC, Pillay D, Charman H, Griffiths PD, Emery VC. Provision of prognostic information in immunocompromised patients by routine application of the polymerase chain reaction for cytomegalovirus. Transplantation 1993; 56: $867-871$.

16. Delgado $\mathrm{R}$, Lumbreras $\mathrm{C}$, Alba $\mathrm{C}$ et al. Low predictive value of polymerase chain reaction for diagnosis of cytomegalovirus disease in liver transplant recipients. J Clin Microbiol 1992; 30: $1876-1878$

17. Einsele H, Ehninger G, Steidle $M$ et al. Polymerase chain reaction to evaluate antiviral therapy for cytomegalovirus disease. Lancet 1991; 338: 1170-1172.

18. Patel R, Smith TF, Espy M et al. Detection of cytomegalovirus DNA in sera of liver transplant recipients. $J$ Clin Microbiol 1994; 32: $1431-1434$.
19. van Dorp WT, Vlieger A, Jiwa NM et al. The polymerase chain reaction, a sensitive and rapid technique for detecting cytomegalovirus infection after renal transplantation. Transplantation 1992; 54: 661-664.

20. Prösch, S, Kimel V, Dawydowa I, Krüger DH. Monitoring of patients for cytomegalovirus after organ transplantation by centrifugation culture and PCR. J Med Virol 1992; 38: $246-251$.

21. Jiwa NM, Raap AK, van de Rijke FM et al. Detection of cytomegalovirus antigens and DNA in tissues fixed in formaldehyde. J Clin Pathol 1989; 42: 749-754.

22. Fox JC, Griffiths PD, Emery VC. Quantification of human cytomegalovirus DNA using the polymerase chain reaction. $J$ Gen Virol 1992; 73: 2405-2408.

23. Schäfer $\mathrm{P}$, Braun RW, Möhring $\mathrm{K}$ et al. Quantitative determination of human cytomegalovirus target sequences in peripheral blood leukocytes by nested polymerase chain reaction and temperature gradient gel electrophoresis. $J$ Gen Virol 1993; 74: 2699-2707.

24. Cone RW, Hobson AC, Huang M-LW. Coamplified positive control detects inhibition of polymerase chain reactions. $J$ Clin Microbiol 1992; 30: 3185-3189.

25. Gerna G, Furione M, Baldanti F, Sarasini A. Comparative quantitation of human cytomegalovirus DNA in blood leukocytes and plasm of transplant and AIDS patients. $J$ Clin Microbiol 1994; 32: 2709-2717.

26. Wang AM, Doyle MV, Mark DF. Quantitation of mRNA by the polymerase chain reaction. Proc Natl Acad Sci USA 1989; 86: 9717-9721. 
